【論 文】

UDC : $628.85: 628.51: 728.1$
日本建築学会計画系論文報告集 第 432 号・1992 年 2 月

Journal of Archit. Plann. Environ. Engng, AIJ, No.432, Feb., 1992

\title{
自然換気の室内における粉塵および金属の性状 CHARACTERISTICS OF PARTICULATE DUSTS AND METALS IN INDOOR AIR WITH NATURAL VENTILATION
}

\author{
宮 崎竹二*, 楢崎 正也** \\ Takeji MIYAZAKI and Masaya NARASAKI
}

\begin{abstract}
Concentrations and size distributions of the particulate dusts and metals in indoor and outdoor air were measured in the expepimental room with Andersen air sampler and low volume air sampler.

It was shown that Indoor/Outdoor concentration ratios and logarithm of MMD for the particulate dusts and metals were correlated closely. I/O concentration ratios and MMD of the indoor particulate dusts and metals when the window was opened, much increased than them when the window was closed. Similar measurement was carried out in a private house to confirm the results above.
\end{abstract}

Keywords : dust, metal, ion, particle size, indoor air 粉塵, 金属, イオン, 粒径, 室内空気

\section{1.はじめに}

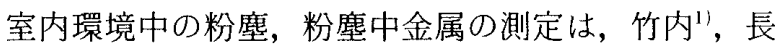
良2)，D.J. Moschandreas ${ }^{31 な と ゙ に よ っ て な さ れ て き た 。 ~}$ 粉塵の測定はそれ自体人体影響の面から重要であるが, 金属の測定は，特に有害な金属については特殊の場合以 外は濃度的にも低いので,あまり重要でないと思われる。 しかし粉塵中金属成分の割合を知ることは，大気中の粉 塺についてよくなされているように，例えば喫煙の寄与 など粉塺の発生源を同定するのに有効である。別報で事 務室なよ゙の粉塵にその手法を適用する予定である。

室内粉塵濃度を考えるとき，外気濃度の影響をまず知 ることが必要であるが, 粉塵の室内濃度と外気濃度との 関係についての研究も，過去には数多くなされてい る ${ }^{4)-81}$ 。しかし，まず室内発塵のない，また除塵されな い自然換気の条件での室内外の関係を調べる必要があ る。室内での発生源がない場合, 空調がなされていない ならば，室内粉塵濃度に影響する因子として外気粉塵濃 度とその粒径分布, 換気量, 開口条件などが考えられる。 また諸因子のうち，外気濃度が変化した場合，その濃度 に比例して室内濃度が決まると考えられている。そこで, いままで粉塵の外気濃度に対する室内濃度の比（以下 I/O 比とする) について0.80 (Biersteker et al.,
$1965)^{99} ， 0.69$ (Ib Andersen，1972) $)^{10)}$ なと值が発表さ れているが，L. Alzona (1979) ${ }^{11}$ によって報告されて いるように，その比は換気量, 粉塺の粒径分布, 開口条 件などによって異なってくると考えられる。

粉塵の粒径分布については, 今回の結果からも外気の MMD (Mass Median Diameter, 質量中央径) は, 0.90-3.8 $\mu \mathrm{m}$ の範囲であるが，金属の MMD について は, 種類により大きく異なり, 今回の外気の結果から, Fe の MMD $5.1 \mu \mathrm{m}$ から V の MMD $0.63 \mu \mathrm{m}$ まで大き く変化するが，1山型の特定の金属に限れば MMD は おおよそ一定である(2)。それゆえ，粒径と $\mathrm{I} / \mathrm{O}$ 比の関 係をみるのに，粉塵濃度だけでなく粉塵中の金属成分も 分析すれば，広い範囲での粒径についての情報を得るこ とができ，その結果，外気の濃度と粒径分布から室内へ の影響をある程度知ることができる。

本研究の目的は, 自然換気亡想定されうる当研究所の 研究室で約 2 年にわたって, 粉塵の発生がない場合につ いて，室内外粉塵および金属濃度とそれらの粒径分布を 測定した結果に基づいて，外気粉塵や金属の MMD と $\mathrm{I} / \mathrm{O}$ 比の関係および換気量と I/O 比の関係について検 討することである(13),14)。また，自然換気の住宅において も同様の測定を行い，研究室の結果と比較検討した ${ }^{151}$ 。

\footnotetext{
本論文の一部については，昭和 63 年度，平成元年度および 2 年度の日本建築学会大会学術講演会にてその概要を発表した。

*大阪书立環境科学研究所・工修 Osaka City Institute of Public Health and Environmental Sciences,

** 大阪大学工学部 教授. I博

Prof., Faculty of Engineering, Univ. of Osaka, Dr. Eng.
} 
それらの関係を知ることによって, 外気の粉塵および 金属濃度やそれらの粒径分布から室内濃度へのそれらの 影響を予測することが可能となる。

\section{2. 測定方法}

\section{1. 研究所における測定}

粉塵および金属の実測に用いた部屋は，当研究所の 7 階の Fig. 1 に示す研究室 (容積, $71 \mathrm{~m}^{3}$ ) である。本来は, 空調がなされているが，吹出し口を塞ぐことによって自 然換気のみとした。吸込み口はない。

粉塵の発生源については，この部屋が倉庫として用い られているため, 測定器の流量の確認やろ紙の取り替え などのため立ち入る以外は入室は少なく，そのため歩行 などによる人体からの発生は少ないと考えられる。契煙 は，この部屋では禁じられている。

測定は, 昭和 61 年 8 月から 63 年 6 月 (中断約 3 力月) まで行ったが, そのうち昭和 62 年 9 月までは部屋の空 を閉めた状態で，奇数月は室内外粉塵および金属濃度之 それらの粒径分布を，2台のアンダーセンエアサンプ ラー (高立機器製, 2100 型, 以下A.S. と略す)により, 前半, 後半の 2 回に分けて測定した。(昭和 61 年 8 月の

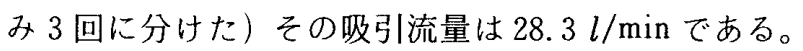
A.S.は，インパクター方式により，粉塵を粒径別に全 部で 9 段に分けて浦集できる測定機である。

偶数月は外気のみ粒径分布の測定を行う一方，1-4 日 の採気日数でローボリウムエアサンプラー(10 $\mu \mathrm{m}$ 以上 の粒子も含む，以下 L. V. と略す）により室内外粉塵お よび金属濃度の測定を行った。A.S.では半月程度の長 期のサンプリングが必要であり，換気量との関係を知る ために L.V.での短期の測定を行った。その吸引流量は $20 \mathrm{l} / \mathrm{min}$ である。

昭和 62 年 10,11 月と昭和 63 年 4, 5, 6 月においては, 部屋の空 (高さ $120 \mathrm{~cm}$, 稫 $73 \mathrm{~cm}$, 開口面積 $0.876 \mathrm{~m}^{2}$ ) を開放して，室内外の粉塵および金属濃度とそれらの粒 径分布の測定を行った。廊下側のドアは閉められている。 また同時に，L.V.による室内外の粉塵および金属の測 定を行った。

トレーサーガス（低濃度での CO）による部屋の換気

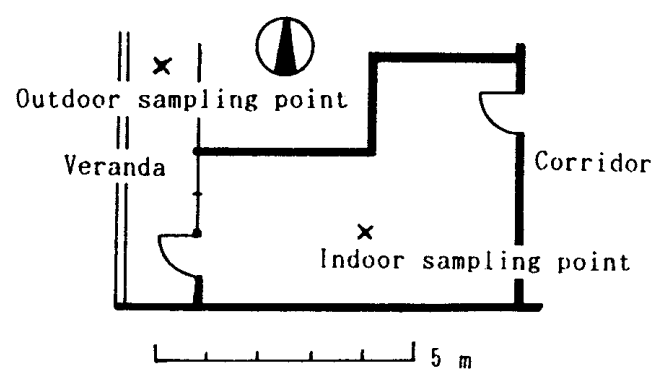

Fig. 1 Room where dust and metals were measured (seventh floor)
回数の測定を，空を閉めた状態で昼間のみ延べ 128 回 行った。また空を開放した状態で，葖中央での風速の連 続測定を, 昭和 62 年 10月 1-5 日の間行った。測定には, 微風速計 (柴田科学) およびデータプリンター(ダイレッ ク製，DY-9000）を用いた。なお，A.S.の吸引流量は $28.3 \mathrm{l} / \mathrm{min}$ なので, 換気回数に変換すると 0.024 回 $/ \mathrm{h}$ となり少ないので，測定による影響は考慮しなかった。

\section{2. 住宅におりる測定}

大阪府下の户建て住宅（以下 $\mathrm{M}$ 宅とする）で，昭和 63 年 11 月 13 日から 12 月 8 日までの期間, 粉塵および 粉塵中金属，イオンの測定を行った。室内での測定箇所 は $2 \mathrm{~F}$ の洋室 (約 $\left.36 \mathrm{~m}^{3}\right)$ 中央であり, 高さ約 $1 \mathrm{~m}$ であ る。この部屋は人の出入りが少なく，また喫煙もなされ ていない。外気は洋室の南側に面したベランダから少し 突き出して測定した。測定方法は，10 $\mu \mathrm{m}$ カットを行わ ずに L.V.（吸引流量は $20 \mathrm{l} / \mathrm{min}$ ) による测定であり, 時間は朝 7 時半頃から夜 10 時頃までである。12月 3 日 と 4 日は, 前半は空を開放し, 後半は閉鎖した。なおそ の他の日は，空はほとんど閉鎖されているが一時開放さ れることがある程度である。

また平成 2 年 4-6月にはA.S. による室内外粉塵濃度 の測定を追加した。室内外の測定は同時ではなく，隔日 に1台のポンプで内外を交互に測定した。吸引流量は $28.3 \mathrm{l} / \mathrm{min}$ であり, 湘定時間はローボリの場合と同様 朝 7 時半頃から夜 10 時頃までである。空の開閉状態は, 季節からしてローボリの測定時期より開放されることが 多かった。

\section{3. 粉塺濃度および粉塵中の金属成分，イオン成分濃} 度の測定

A.S.および L.V.とも, 粉塵の捕集には石英ろ紙（東 洋ろ紙 QR 100）を用い，万紙の科量は恒温恒湿室（温 度 $20^{\circ} \mathrm{C}$, 湿度 $50 \%$ ）に 1 日以上放置後行った。

金属の测定は, A.S.では研究室の場合 1 力月分を, 住宅の場合 3 力月分をひとまとめにして分析した。 L.V.では研究室，住宅ともに 1 月分ごとに粉塵濃度ラ ンク別に2-8 日分をひとまとめにして分析した。分析方 法は, 万紙の半分について硝酸, 過塩素酸で湿式灰化後 $\mathrm{V}, \mathrm{Mn}, \mathrm{Fe}, \mathrm{Cu}, \mathrm{Zn}, \mathrm{Cd}, \mathrm{Pb}$ を原子吸光光度法で分 析した。残りのうち, 万紙の $1 / 4$ について, 蒸留水で超 音波抽出後, 同じく原子吸光光度法によって $\mathrm{Na}^{+}, \mathrm{Mg}^{2+}$, $\mathrm{K}^{+}, \mathrm{Ca}^{2+}$ を分析した。 $\mathrm{M}$ 宅では，水抽出試料について $\mathrm{Cl}^{-}, \mathrm{NO}_{3}^{-}, \mathrm{SO}_{4}^{2-}, \mathrm{NH}_{4}^{+}$のイオンの分析を追加したが, イオンクロマトグラフィーによった。これらの金属やイ オンは, 浮遊状態では酸化物や塩などの形で存在してい ると思われる。

粉塵および金属の粒径分布の作図は，粒径の累積度数 分布曲線を粒径の対数で微分することにより求めたが, その簡易計算法である角脇による方法によった 


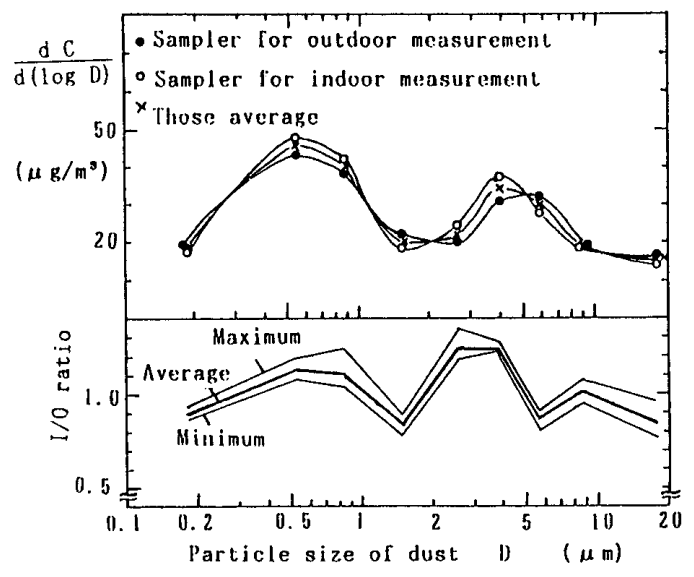

Fig. 2 Comparison of two Andersen air samplers

\section{4. アンダーセンの機差}

研究所や住宅の室内外の粉塵および粉塵中金属の粒径 分布を比較する前に，外気測定用と室内测定用の A.S. の機差について検討した。測定期間は，昭和 62 年 12 月 から 63 年 2 月にかけてであり, 外気について 5 回行っ た機差試験の結果をFig. 2 に示す。粉塵濃度について は外気用 $61.6 \mu \mathrm{g} / \mathrm{m}^{3}$ に対して室内用 $60.7 \mu \mathrm{g} / \mathrm{m}^{3}$ とほ之 んど差がない。粒径分布については機差がみられるもの の常に一定の傾向にあるので，機差試験の結果から，室 内用，外気用ともに各ステージの重量割合がそれらの平 均值になるように補正係数を求め，それを掛けることに より補正した。以下，すべて補正後のデータに基づいて いる。

\section{3. 測定結果}

3.1. 研究所における粉塵濃度, 粉塵中金属成分濃度お よび換気回数の測定

\section{(1) A.S.の測定結果}

室内外の粉塵濃度およびその MMD の経月変化を Fig. 3 に示す。外気については，冬に粉糜濃度は高く, MMD は小さく，夏にそれらの逆になる傾向が認めら れる。室内については，濃度，MMD ともほぼ一定で ある。

空を閉めた状態での室内外の粉塵，および金属のうち $\mathrm{Mn}, \mathrm{Fe}, \mathrm{Pb}$ についてのみ粒径分布を，Fig.4に示す。 外気は昭和 61 年 8 月から昭和 62 年 9 月までの平均（粉 塺 $\mathrm{N}=31$ ，金属 $\mathrm{N}=15$ ），室内は昭和 61 年 9，11，昭和 62 年 $1,3,5,7,9$ 月の平均（粉塵 $\mathrm{N}=14$, 金属 $\mathrm{N}=7$ ) である。

悹を開けた状態での同様の結果を，Fig. 5 に示す。室 内外之も, 昭和 62 年 10,11 月之昭和 63 年 5,6 月の平 均（粉塵 $\mathrm{N}=8$, 金属 $\mathrm{N}=4$ ）である。昭和 63 年 4 月後 半は，黄砂現象がみられた時であり，平均值からは除い た。

外気の粉塵, $\mathrm{Mn}$ の粒径分布は, $0.5 \mu \mathrm{m}$ と $4 \mu \mathrm{m}$ 付近

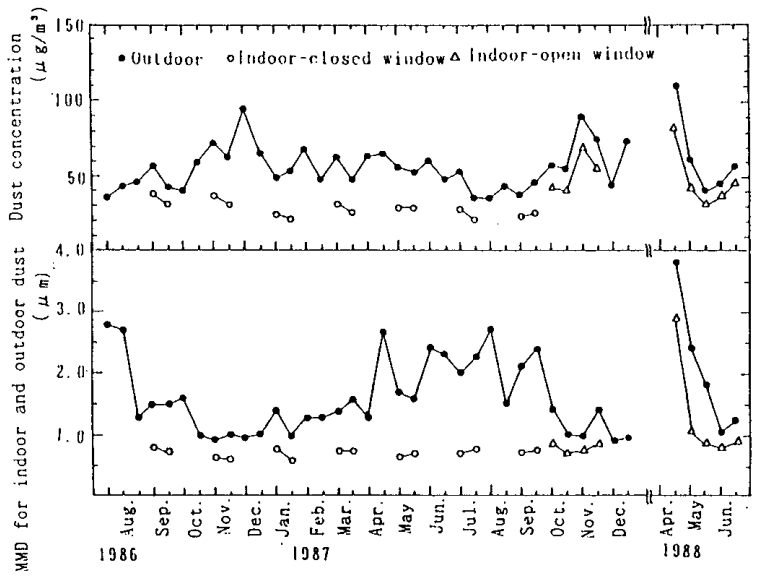

Fig. 3 Changes of outdoor and indoor dust concentrations and those MMD

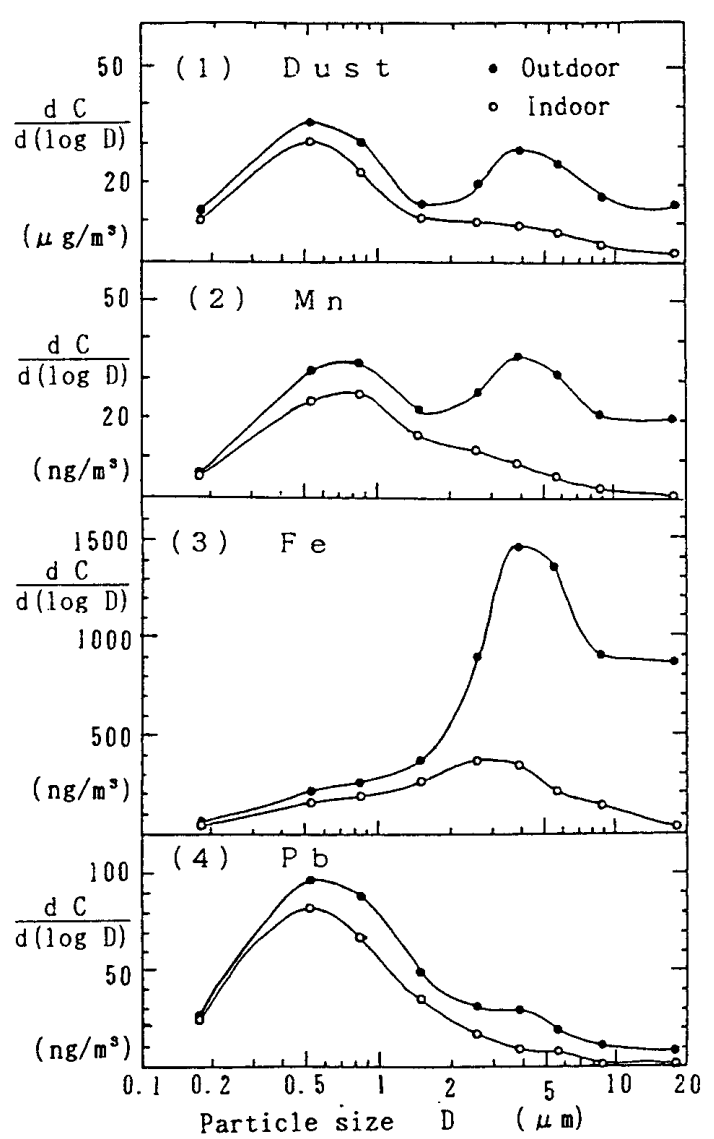

Fig. 4 Size distributions of dust, $\mathrm{Mn}, \mathrm{Fe}$ and $\mathrm{Pb}$ (closed window)

にピークを示す 2 山型を示し, $\mathrm{Fe}$ は大粒径に, $\mathrm{Pb}$ は 小粒径にピークをもつ1山型を示す。室内でのそれらの 粒径分布は，外気と比較して大粒径ほざ低くなる。空を 開放すれば，閉じた時より外気に粒径分布が近くなる。

今回の測定期間中において，外気の粉塺の MMD（以 下 $\mathrm{MMD}_{0}$ とする) の範囲は, 黄砂時の $3.8 \mu \mathrm{m}$ は例外 として最大 $2.8 \mu \mathrm{m}$ ，最小 $0.9 \mu \mathrm{m}$ である。それに対して 金属については, 1 山型の金属の場合粒径の大きい順に, Fe 7.8-4.2 $\mu \mathrm{m}, \mathrm{Ca}^{2+} 5.0-3.1 \mu \mathrm{m}, \mathrm{Mg}^{2+} 4.2-2.6 \mu \mathrm{m}$, Zn 1. 5-1.05 $\mu \mathrm{m}, \mathrm{Pb} 1.05-0.69 \mu \mathrm{m}, \mathrm{K}^{+} 0.88-0.58 \mu \mathrm{m}$, $\mathrm{Cd} 0.83-0.57 \mu \mathrm{m}$ であり $\mathrm{MMD}_{0}$ の変化は少ない。2山 型の $\mathrm{Mn}$ では 4.6-1.5 $\mu \mathrm{m}$ と，粉塵之同様に広範囲であ 


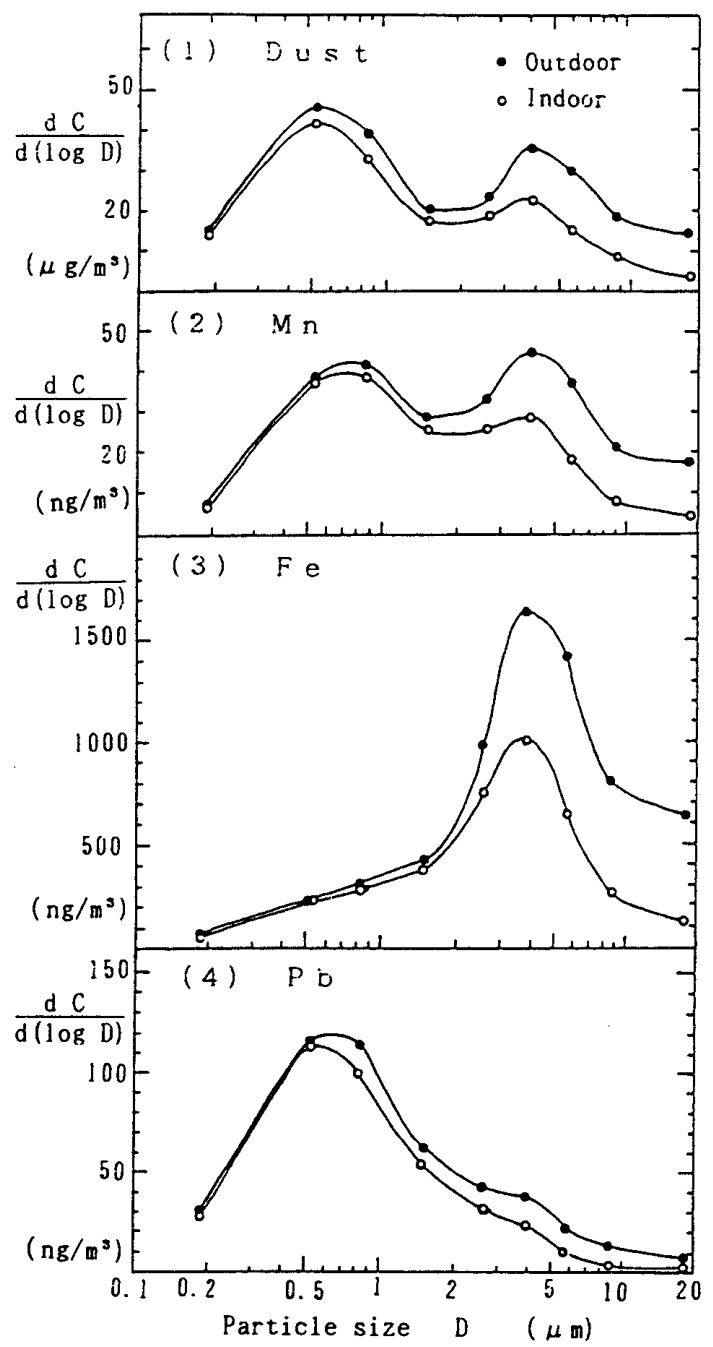

Fig. 5 Size distributions of dust, $\mathrm{Mn}, \mathrm{Fe}$ and $\mathrm{Pb}$ (open window)

る。2山型の粉鹿や金属はそれぞれのピークに対応した 少なくとも 2 つ以上の発生源をもっていることになり， それ故 $\mathrm{MMD}_{0}$ が大きく変化する。

\section{(2) L.V.の測定結果}

空閉鎖時の測定回数 $\mathrm{N}$ は 140 であり, 粉塵濃度の平 均および標隻偏差は外気 $65.9 \pm 34.6 \mu \mathrm{g} / \mathrm{m}^{3}$, 室内 32.1 $\pm 13.0 \mu \mathrm{g} / \mathrm{m}^{3}$ であった。これらのデータのうち，風向 が比較的一定の時のデー夕を, 換気量と $\mathrm{I} / \mathrm{O}$ 比の関係 を調べるのに用いた。粉塵中金属成分濃度は，分析した が今回の解析には用いなかった。

空開放時の測定回数 $\mathrm{N}$ は 35 であり, 粉塵濃度の平均 および標準偏差は外気 $89.2 \pm 44.7 \mu \mathrm{g} / \mathrm{m}^{3}$, 室内 $54.7 \pm$ $27.2 \mu \mathrm{g} / \mathrm{m}^{3}$ であった。外気濃度は，空閉鎖時と此較する 之, 高かった。

\section{(3) 換気回数の測定結果}

トレーサーガスによる部屋の換気回数の測定を, 空を 閉めた状態で昼間のみ延べ 128 回行ったが，その平均お よび標準偏差は $1.18 \pm 0.69$ 回/hであった。換気回数の 算出方法は, Seidel の式によった。またその時の大阪 管区気象台（当研究所の北西 $2.3 \mathrm{~km}$ に位置する）の風 向, 風速データより西風の場合の風速之換気回数亡の関

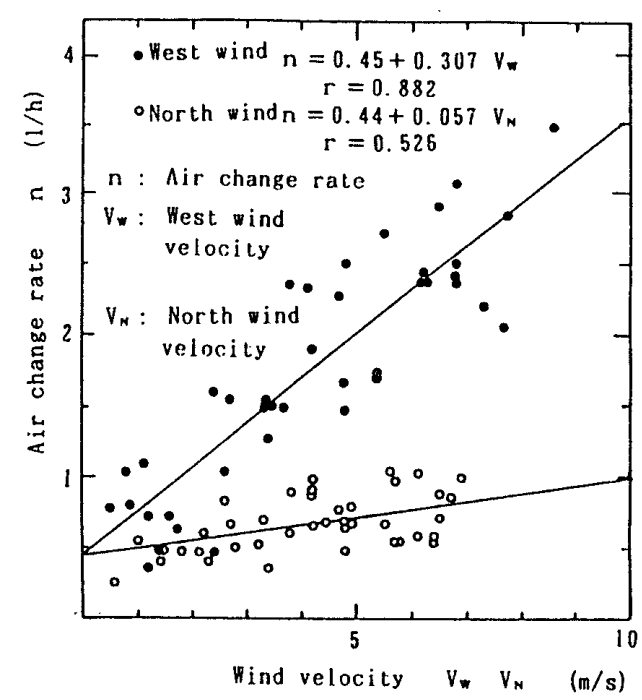

Fig. 6 Air change rate as a function of wind velocity (closed window )

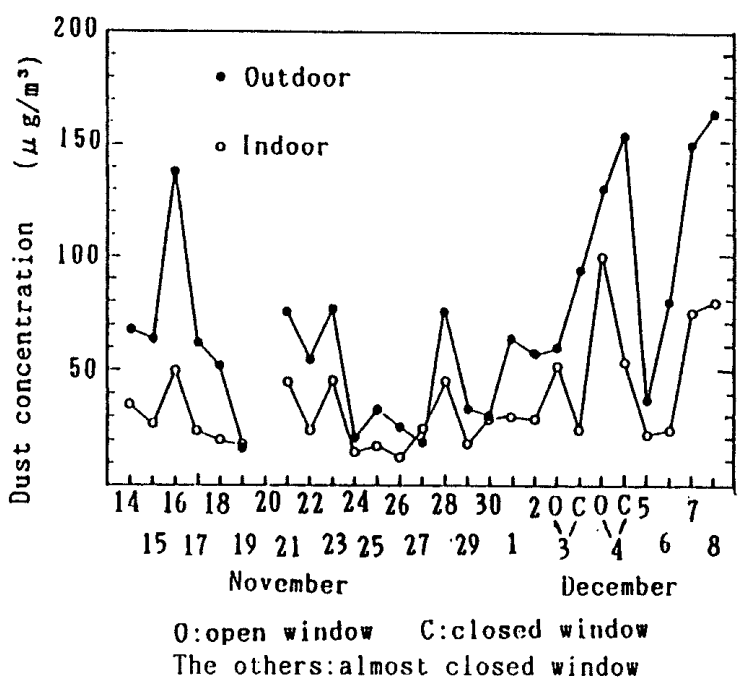

Fig. 7 Changes of dust concentration at Home M (L.V.)

係, 北風の場合の風速と換気回数との関係を求めたのが Fig. 6 である。ただし, 西北西から西南西の範囲の風を 西風, 北北西から北北東の範囲の風を北風とした。部屋 の空が西向きであり，ベランダの奥にあるため，北風に よる換気回数の増加は少ないが, 西風では著しく増加し, 相関も高い。

悹を開放した状態で，悹中央での風速の連続測定を 行ったが，その期間は風速は比較的榣やかであった。そ の平均風速が $0.086 \mathrm{~m} / \mathrm{s}$ であることから予想される換気 回数は 3.8 回/hであった。風向については, 数回の測 定より西側のベランダから東側の廊下への気流が主体で あるが，逆の場合もあった。

3.2. 住宅における粉塵濃度, 粉塵中金属成分, イオン 成分濃度の測定

(1) L.V.の測定結果

住宅における測定結果をFig. 7 に示す。室内粉塵濃 度は，窓をほとんど閉鎖し，時折開放する程度の一般の 日（以下「通常」とする）と比較して，空を開放した 3 


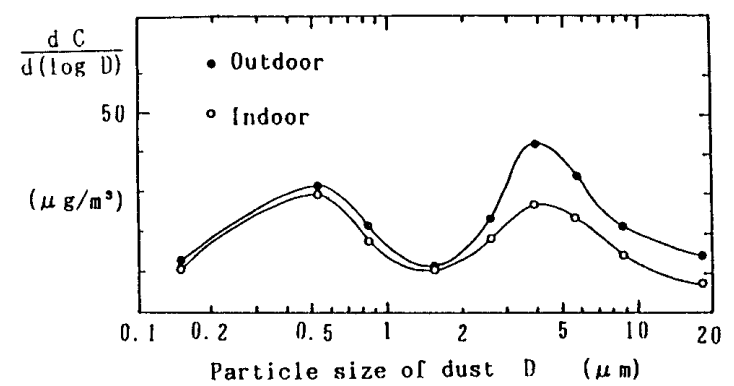

Fig. 8 Size distribution of dust at Home $M$

日と 4 日の前半は外気濃度に近くなるが，窓を閉鎖した 同日の後半は外気濃度に比較して低くなる。

「通常」での粉塵濃度の平均および標準偏差は, 外気 について $63.6 \pm 39.9 \mu \mathrm{g} / \mathrm{m}^{3}$, 室内について $32.3 \pm 17.6$ $\mu \mathrm{g} / \mathrm{m}^{3}$ であった。空開放での外気の平均濃度は 95.0 $\mu \mathrm{g} / \mathrm{m}^{3}$ であり,「通常」での值より高く, 空閉鎖での平 均濃度は $124.0 \mu \mathrm{g} / \mathrm{m}^{3}$ とさらに高かった。

\section{(2) A.S.の測定結果}

粉塺濃度は外気 $50.7 \mu \mathrm{g} / \mathrm{m}^{3}$, 室内 $38.4 \mu \mathrm{g} / \mathrm{m}^{3}$ であり, L.V. . 濃度と比較して外気は低く, 逆に室内は高い。 室内外の粉塵の粒径分布についてのみ Fig. 8 に示すが, 大粒径では室内が外気に比較してある程度低くなるが， 小粒径ではそれほよ゙違わない。

\section{4. 考察}

4.1. 研究所における外気粉塵濃度と $\mathrm{MMD}_{0}$ の関係 室内と関係付けるための外気粉塵濃度 $\left(\mathrm{C}_{0}\right.$ とする $)$ とその $\mathrm{MMD}_{0}$ の関係を Fig. 9 に示す。全体では相関係 数はそれほざ高くないが, 室内を測定しているときの空 閉鎖時に限ればー0.733 と高い負の相関を示す。高濃度 が小粒径粒子の増加によって生じることが多いことを示 している。

また，比較的風向が安定しているときの L.V.の測定 期間中の平均風速之外気粉塵濃度の関係を北風之西風に わけて Fig. 10 に示すが, ともに高い負の相関である。

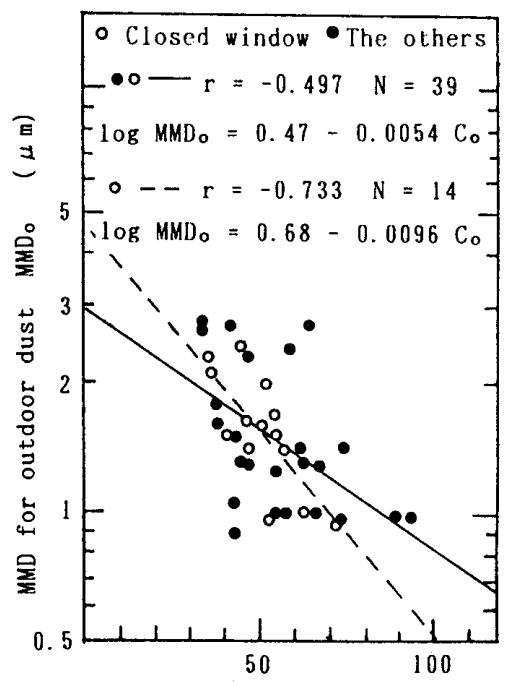

Outdoor dust concentration $C_{0} \quad\left(\mu \mathrm{g} / \mathrm{m}^{3}\right)$

Fig. 9 MMD for outdoor dust as a function of outdoor dust concentration

先のFig. 6 に示したように，風速と換気量との間に高 い正の相関があったことから，風速により換気量が増え る状況では，外気粉塵濃度が低くなる傾向にある。

4.2. 研究所における外気粉塵濃度と $\mathrm{I} / \mathrm{O}$ 比の関係

L.V.による外気粉塵濃度と I/O 比の関係を Fig. 11 に示す。空を閉鎖した場合，I/O 比は濃度と負の相関で あるが, 空を開放した場合, 濃度が変化しても $I / O$ 比 はそれほど変わらない。

A.S. での外気粉鹿濃度と I/O 比の関係を Fig. 12 に 示す。その傾向は L.V.の場合と同様であるが，窓閉鎖 あるいは開放どちらの場合も A.S. での I/O 比が L.V. の場合と比較して高いのは，測定期間が長時間のため平 均化され，外気粉塵濃度の範囲が狭くなっていることも 一因であると考えられる。

\section{3. 研究所における $\mathrm{MMD}_{0}$ と $\mathrm{I} / \mathrm{O}$ 比の関係}

A.S.の各ステージにおける粉塵の I/O 比を Fig. 13 に示すが，空閉鎖，開放の場合共に粒径が $2 \mu \mathrm{m}$ 以下で は $\mathrm{I} / \mathrm{O}$ 比はそれほど変化しないが， $2 \mu \mathrm{m}$ 以上では $\mathrm{I} / \mathrm{O}$

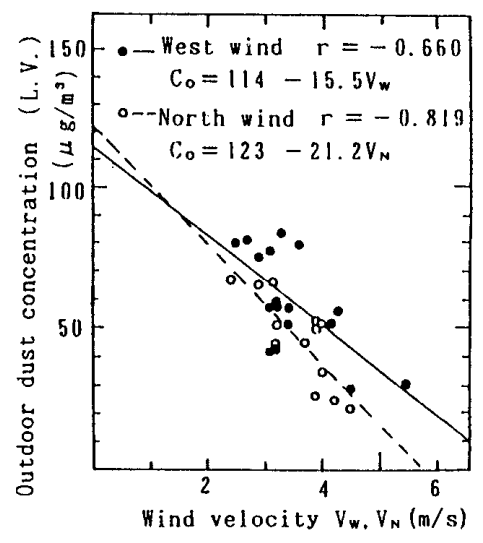

Fig. 10 Outdoor dust concentration (L.V.) as a function of wind velocity

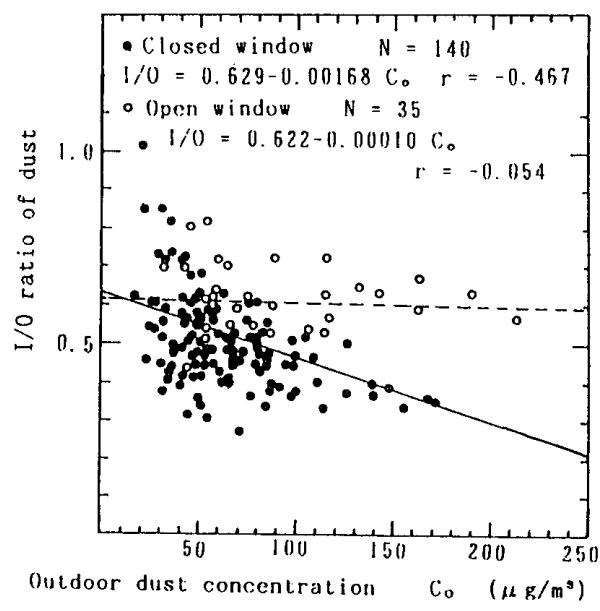

Fig. 11 I/O ratio as a function of outdoor dust concentration (L.V.)

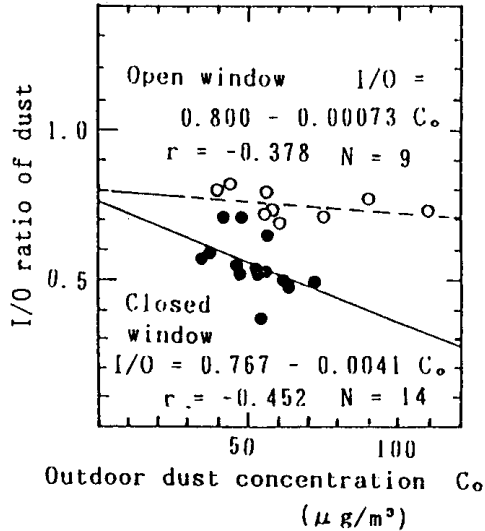

Fig. 12 I/O ratios of dust as a function of outdoor dust concentration 
比は著しく低下する。

粉塵についての $\mathrm{MMD}_{0}$ の対数と $\mathrm{I} / \mathrm{O}$ 比の関係を Fig. 14 に示すが，相関は低く，また空を閉めた場合正 の相関であり，大粒子はサッシなどのフィルタ一効果に より室内に侵入しにくいことからすると矛盾する。その 原因として，外気粉塵濃度が高い時， $\mathrm{MMD}_{0}$ は小さく なり (Fig. 9)，1/O 比も小さくなり (Fig. 12), 結果と して $\mathrm{MMD}_{0}$ と $\mathrm{I} / \mathrm{O}$ 比の間に正の相関がみられたと考え られる。

A.S.での粉塵，金属濃度およびそれらの MMD の測 定結果を Table 1 (空閉鎖)，Table 2 (空開放)に示す。 Fig. 4, Fig. 5 と同じ期間での平均值である。それらの 結果より，粉塵および金属の $\mathrm{MMD}_{0}$ の対数と $\mathrm{I} / \mathrm{O}$ 比の

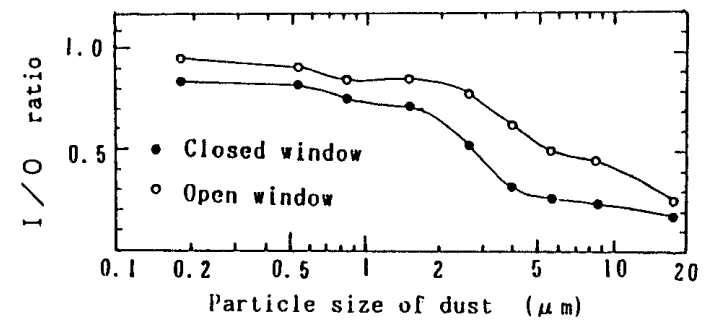

Fig. 13 I/O ratios as a function of particle size of dust

Table 1 Concentration and MMD for dust and metals (closed window )

\begin{tabular}{|c|c|c|c|c|c|}
\hline & \multicolumn{2}{|c|}{$\begin{array}{c}\text { Concentration } \\
n g / \mathrm{m}^{3}\end{array}$} & \multirow{2}{*}{ I/0 ratio } & \multicolumn{2}{|c|}{$\begin{array}{l}\text { MADD } \\
\mu \mathbb{D}\end{array}$} \\
\hline & Indoor & Outdoor & & Indoor & Jutdoor \\
\hline Dust & $27.7^{\circ}$ & $49.2^{\circ}$ & 0.56 & 0.70 & 1.45 \\
\hline $\mathrm{Na}^{*}$ & 849 & 1540 & 0.55 & 1.20 & 2.4 \\
\hline $\mathrm{Mg}^{2+}$ & 61 & 151 & 0.40 & 1.8 & 3.8 \\
\hline $\mathrm{K}^{*}$ & 294 & 422 & 0.70 & 0.59 & 0.70 \\
\hline $\mathrm{Ca}^{2+}$ & 302 & 737 & 0.41 & 1.35 & 4. 0 \\
\hline v & 3. 41 & 5.15 & 0.66 & 0.50 & 0.63 \\
\hline Mn & 24.2 & 53.8 & 0.45 & 0.89 & 2.6 \\
\hline $\mathrm{Fe}$ & 384 & 1434 & 0.27 & 2.2 & 5.1 \\
\hline $\mathrm{Ni}$ & 6.4 & 10.3 & 0.62 & 0.92 & 1.30 \\
\hline $\mathrm{Cu}$ & 19.9 & 37.7 & 0.53 & 0.70 & 1.6 \\
\hline $\mathrm{Zn}$ & 179 & 268 & 0.67 & 0.84 & 1. 25 \\
\hline $\mathrm{Cd}$ & 2.35 & 2.98 & 0.79 & 0.57 & 0.66 \\
\hline $\mathrm{Pb}$ & 62.6 & 89.9 & 0.70 & 0.62 & 0.80 \\
\hline
\end{tabular}

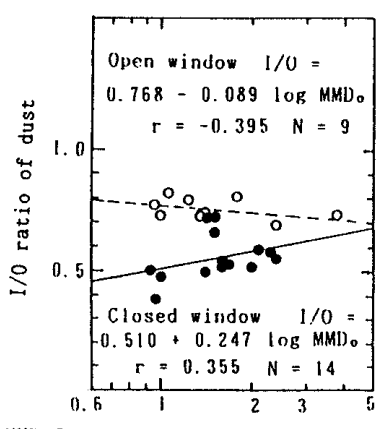

MMI) for outdoor dust MMlo $(\mu \mathrm{m})$

Fig. 14 1/O ratios of dust as a function of MMD for outdoor dust

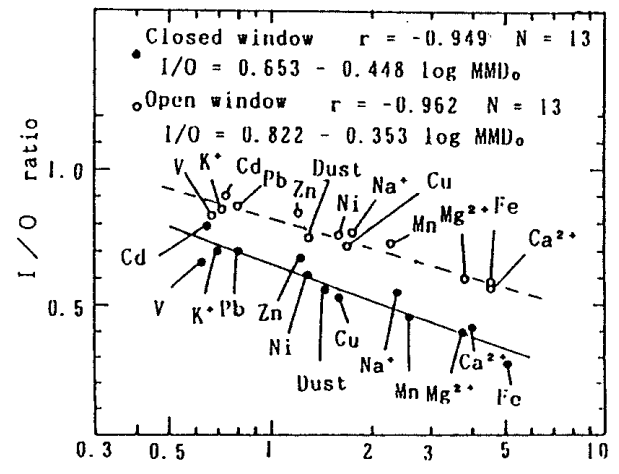

MMI) for outdoor dust and metals $\operatorname{MMD}_{0}$ ( $\mu$ m)

Fig. 15 I/O ratios as a function of MMD for outdoor dust and metals
関係を，空を開けた場合と閉めた場合について Fig. 15 に示す。両方とも高い負の相関を示しているが，空を閉 めた方が開けた場合より I/O比が低くなる。粉塺につ いての Fig. 14 では，空閉鎖の場合正の相関であった。 粉鹿の場合, 各データについては外気濃度, 気象条件な ども異なってくるが，Fig. 15 では長期間の同一谷象条 件での結果のため相関が高くなったと考えられる。

粉塺の各粒径範囲別にみると（Fig. 13), 粒径が 2 $\mu \mathrm{m}$ 以下ではI/O比がそれはよ゙変わらないが，2 $2 \mathrm{~m}$ よ り大きくなるにつれてその比が小さくなるのに対して， 粉塵や金属の MMD と $1 / 0$ 比との関係では直線的とな る (Fig. 15)。

4.4. 研究所における $\mathrm{MMD}_{0}\left\llcorner\mathrm{MMD}_{1}\right.$ の関係

粉塵についての $\mathrm{MMD}_{0}$ の対数と室内での MMD（以 下 $\mathrm{MMD}_{1}$ とする) の対数の関係は, Fig. 16 に示すとお り，相関はある程度高く，特に空開放の場合相関係数は 0.911 である。

粉塵および金属についての $\mathrm{MMD}_{0}$ と $\mathrm{MMD}_{1}$ の関係 をFig. 17 に示すが，高い正の相関を示す。小粒径では 空の開閉による差は少ないが, 大粒径ではその差は大き

Table 2 Concentration and MMD for dust and metals (open window )

\begin{tabular}{|c|c|c|c|c|c|}
\hline & \multicolumn{2}{|c|}{$\begin{array}{c}\text { Concentration } \\
n g / m^{3}\end{array}$} & \multirow{2}{*}{ I/0 ratio } & \multicolumn{2}{|c|}{$\begin{array}{l}\text { MMD } \\
\mu m\end{array}$} \\
\hline & Indoor & Outdoor & & Indoor & Outdoor \\
\hline Dust & $43.9^{\circ}$ & $58.7^{\circ}$ & 0.75 & 0.85 & 1.30 \\
\hline $\mathrm{Na}^{*}$ & 1450 & 1880 & 0.77 & 1.20 & 1.75 \\
\hline $\mathrm{Mg}^{2}$, & 82 & 137 & 0.60 & 2.6 & 3.8 \\
\hline $\mathrm{K}^{*}$ & 388 & 459 & 0.85 & 0.63 & 0.72 \\
\hline $\mathrm{Ca}^{2+}$ & 401 & 705 & 0.57 & 2.8 & 4.6 \\
\hline$v$ & 4. 31 & 5.22 & 0.83 & 0.53 & 0.68 \\
\hline Mn & 45.5 & 62.5 & 0.73 & 1.30 & 2.3 \\
\hline $\mathrm{Fe}$ & 811 & 1407 & 0.58 & 3.2 & 4.6 \\
\hline $\mathrm{Ni}$ & 6.8 & 90 & 0.76 & 1.2 & 1.6 \\
\hline $\mathrm{Cu}$ & 32.3 & 44.1 & 0.73 & 0.89 & 1.7 \\
\hline $\mathrm{Zn}$ & 278 & 330 & 0.84 & 1.00 & 1. 20 \\
\hline $\mathrm{Cd}$ & 2.94 & 3.26 & 0.90 & 0.68 & 0.74 \\
\hline $\mathrm{Pb}$ & 94 & 109 & 0.86 & 0.72 & 0.80 \\
\hline
\end{tabular}

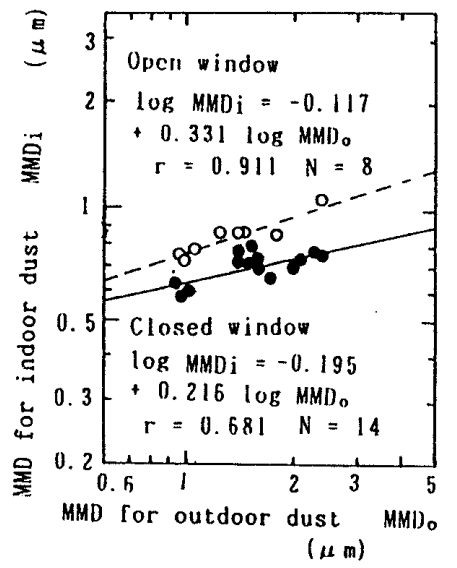

Fig. 16 MMD for indoor dust as a function of $\mathrm{MMD}$ for outdoor dust 


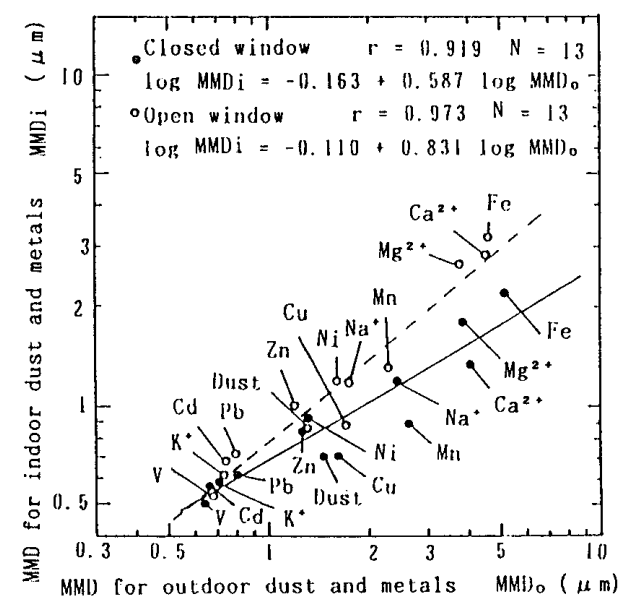

Fig. 17 MMD for indoor dust and metals as a function of MMD for outdoor dust and metals

くなる。粉塺についての Fig. 16 と比較すると，粒径範 囲が広く，また傾きも大きくなっている。

4.5. 研究所における換気量と $\mathrm{I} / \mathrm{O}$ 比の関係

空を開放することによる換気量の増加は, Fig. 11, Fig. 12 に示したように，I/O 比を増加させるが，空を 閉鎖した状態での換気量の増減の I/O 比に及ぼす影響 について検討した。

先述したように，北風あるいは西風別には風速と換気 回数之の間に正の相関関係があることから，換気量の代 わりに風速と L.V.Vよる粉塵の $\mathrm{I} / \mathrm{O}$ 比との関係をみた が Fig. 18 である。北風の場合，風速が高いほど $\mathrm{I} / \mathrm{O}$ 比 も高くなっている。その原因として，Fig. 10 に示され ているように, 風速が高いほよ゙外気粉塵濃度が低くなり, また先にFig.11で示したように，外気粉塵濃度が低い ほどI/O 比が高くなることが考えられる。

西風の場合, 北風と比較して同程度の風速であ机ば, Fig. 6 上り換気量は多いと思われるが，I/O 比はそれほ ビ違わない。空を閉鎖した状態での外部風速による換気 量の増加の I/O 比への影響はそれほど大きくはないと 思われる。

4.6. 住宅における外気粉塵濃度と $I / O$ 比の関係

L.V.による外気粉鹿濃度と I/O 比の関係を Fig. 19 に示す。「通常」と比較して例数は少ないが，空を開放 する之，その比が大きくなり，公を閉鎖するとその比が 小さくなることが示されている。

$\mathrm{I} / \mathrm{O}$ 比に外気粉塵濃度が影響することから，空開放お よび空閉鎖の場合と外気粉塵濃度の条件をできる限り一 致させるために，外気粉塵濃度が $70 \mu \mathrm{g} / \mathrm{m}^{3}$ 以上の日の みを選び求めた「通常」での粉㢈および金属の平均濃度 と，空開放および空閉鎖の場合の平均濃度を Table 3 に 示す。粉塺の $\mathrm{I} / \mathrm{O}$ 比は, 空開放の場合 0.80 , 空閉鎖の 場合 0.31 であるのに対し，「通常」ではその間の 0.48 であった。

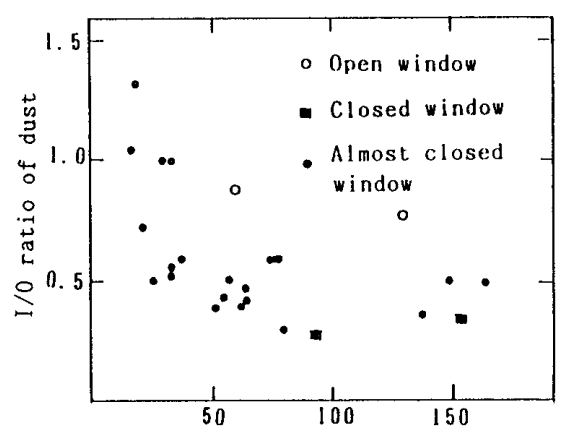

Ouldoor dust concentration $\left(\mu \mathrm{g} / \mathrm{m}^{3}\right)$

Fig. 19 I/O ratio of dust as a function of outdoor dust concentration at Home M (L.V.)

Table 3 Concentrations of dust, metals and ions at Home $M$ (L.V.)

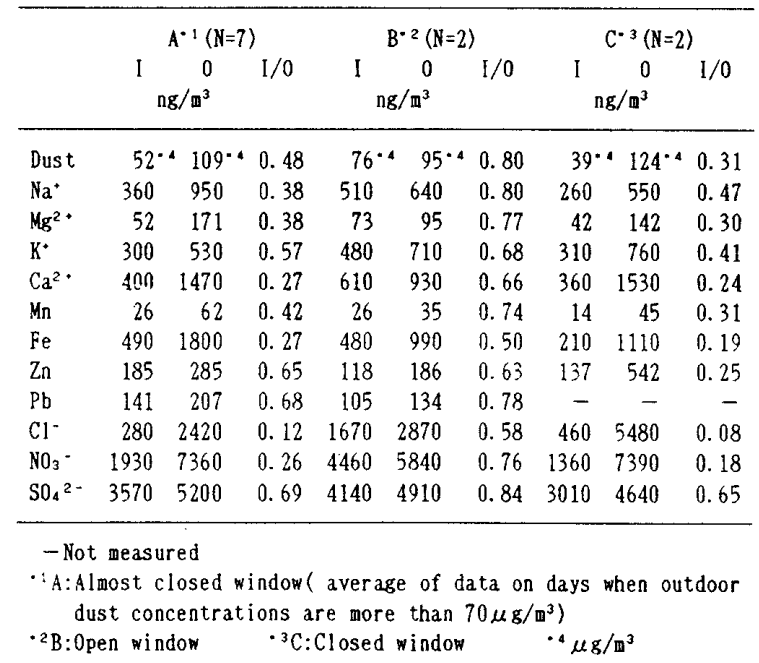

Table 4 Concentrations and MMD for dust, metals and ions at Home M (Apr. -Jun. 1990)

\begin{tabular}{|c|c|c|c|c|c|}
\hline & \multicolumn{2}{|c|}{$\begin{array}{c}\text { Concentration } \\
\mathrm{ng} / \mathrm{m}^{3}\end{array}$} & \multirow{2}{*}{ I/0 ratio } & \multicolumn{2}{|r|}{$\begin{array}{l}\text { MMD } \\
\mu \mathrm{m}\end{array}$} \\
\hline & Indoor & Outdoor & & Indoor & Outdoor \\
\hline Dust & $38.4^{\circ}$ & $50.7^{\circ}$ & 0.76 & 1.8 & 2.7 \\
\hline $\mathrm{Na}^{*}$ & 328 & 533 & 0.61 & 1.8 & 2.8 \\
\hline $\mathrm{Mg}^{2} \cdot$ & 59.8 & 118.0 & 0.51 & 2.6 & 3.3 \\
\hline $\mathrm{K}^{+}$ & 301 & 321 & 0.94 & 0.63 & 0.67 \\
\hline $\mathrm{Ca}^{2+}$ & 401 & 551 & 0.73 & 2.9 & 4.1 \\
\hline v & 2.8 & 4. 2 & 0.67 & 0.42 & 0. 48 \\
\hline$M n$ & 18.6 & 31.8 & 0.58 & 2.0 & 3.4 \\
\hline $\mathrm{Fe}$ & 614 & 1054 & 0.58 & 4.0 & 4.4 \\
\hline $\mathrm{Zn}$ & 74.5 & 113.4 & 0.66 & 0.75 & 0.83 \\
\hline $\mathrm{Cd}$ & 0.79 & 1. 11 & 0.71 & 0.70 & 0.84 \\
\hline $\mathrm{Pb}$ & 39.9 & 48.4 & 0.82 & 0.65 & 0.83 \\
\hline $\mathrm{NH}_{4}{ }^{*}$ & 1409 & 1604 & 0.88 & 0.49 & 0.53 \\
\hline $\mathrm{Cl}^{-}$ & 133 & 299 & 0.44 & 4.9 & 4.5 \\
\hline $\mathrm{NO}_{3}^{-}$ & 834 & 1435 & 0.58 & 3.6 & 4.1 \\
\hline $\mathrm{SO}_{4}{ }^{2-}$ & 5106 & 6142 & 0.83 & 0.58 & 0.67 \\
\hline
\end{tabular}

A.S.の測定結果をTable 4 に示す。A.S.での I/O 比 は L.V.の悹開放時の I/O 比に近い。その原因として, 測定時の空の開閉の程度が異なることもあるが，A.S. での外気濃度が L.V.と比較して低いことがあげられ る。 


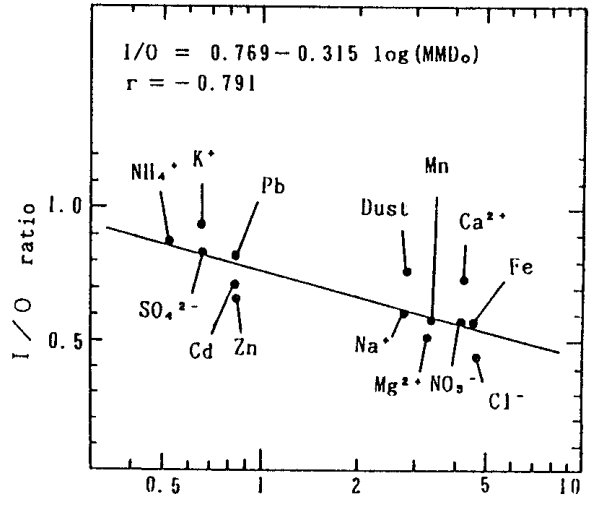

MMD for outdoor dust, melals and ions $M M D_{0}(\mu \mathrm{m})$

Fig. 20 I/O ratio as a function of MMD for outdoor dust, metals and ions at Home $\mathrm{M}$

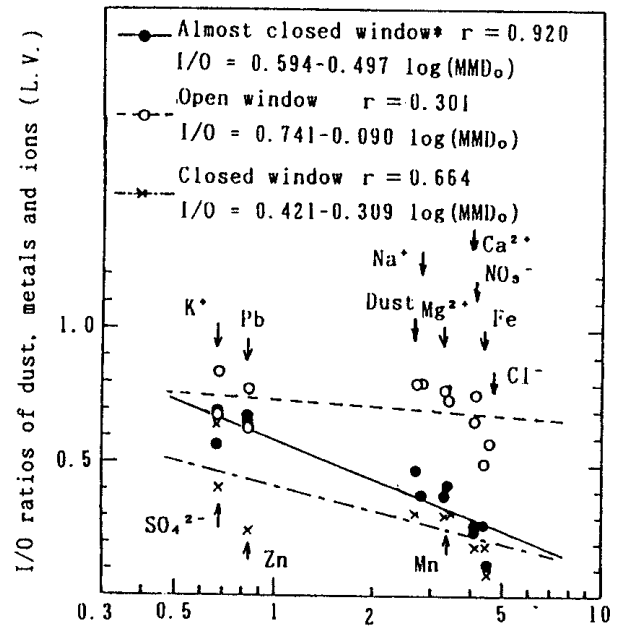

MMD for outdoor dust, metals and ions ( $\Lambda . S).(\mu \mathrm{m})$ * Average of data on days when outdoor dust concentrations were more than $70 \mu \mathrm{g} / \mathrm{m}^{3}$

Fig. 21 1/O ratios of dust, metals and ions (L.V.) as a function of MMD for outdoor those at Home M

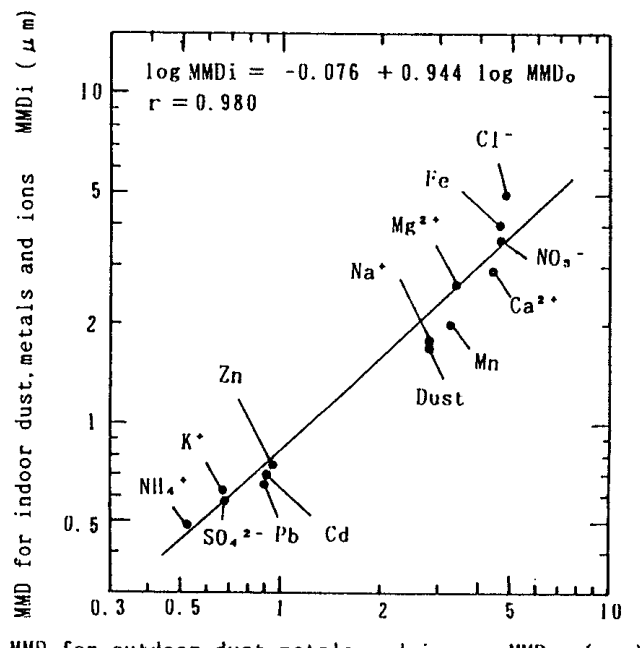

MMD for outdoor dust, metals and ions MMDo ( $\mu \mathrm{m})$

Fig. 22 MMD for indoor dust, metals and ions as a function of MMD for outdoor those at Home M

4.7. 住宅における $\mathrm{MMD}_{0}$ と $\mathrm{I} / \mathrm{O}$ 比の関係

A.S.のデータより粉塵抽よび金属，イオンの $\mathrm{MMD}_{0}$ と I/O 比の関係を示したのが Fig. 20である。相関係数
はー0.791 と高く, その回帰直線は研究所での悹開放之 閉鎖の間にある。

A.S.の粉塵および金属，イオンの $\mathrm{MMD}_{0}$ と L.V.の 空開閉別の I/O 比との関係をみたのが Fig. 21 である。 空閉鎖および開放時の相関係数はデータが少ないためも ありそれほど高くないが，窓を開放することによる MMD の大きな金属の I/O 比の増加が示されている。

金属種のI/O 比については，A.F. Cohenによ机ば

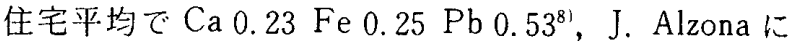
よれば気密性の高い住宅の寝室で Fe 0.27 Pb 0.70, 機 密性の低い住宅の葠室で Fe 0.33 Pb 0.47などの値が 出されているが"1，それらの值は今回の結果のうち空閉 鎖時の研究室での結果と近似している。

4.8. 住宅における $\mathrm{MMD}_{0}$ と $\mathrm{MMD}_{1}$ の関係

A.S.の粉塺および金属，イオンの $\mathrm{MMD}_{0}$ と $\mathrm{MMD}_{\mathrm{i}}$ との関係を Fig. 22 に示すが，相関係数も 0.980 と高い。 短期間での住宅での測定結果ではあるが，長期間での研 究所での測定結果と傾向が一致している。

\section{5.まとめ}

外気粉塵による室内影響を予測するとき, 室内発生が ない場合, 室内濃度は外気濃度に一定の係数 ( $\mathrm{I} / \mathrm{O}$ 比) を乗じて得られれば便利である。本来，I/O 比は，自然 換気の場合，外気濃度に無関係に，外気の粒径分布，開 口条件，換気量などによって決まると考えられる。すな わち粒径が大きければ，I/O 比は小さく，空を開放して いれば閉鎖したときと比較して大きく，換気量が大きけ れば大きくなると推測される。

発生源がほとんどないと考えられる，吹出し口を塞い だ部屋および自然換気の住宅で，室内外の粉塵および金 属，イオン濃度とそれらの粒径分布の測定を行い，以下 の結論を得た。

1）開口条件，換気量が一定の時，外気粉塺の粒径が 大になると，室内への流入時のフィルター効果や室内で の沈積作用か強く作用し，濃度の減少割合，すなわち I/O 比は小さくなることが実証できた。開口条件，換気 量が一定ならば，外気の粒径分布 $\left(\mathrm{MMD}_{0}\right)$ が得られ ると，I/O 比がある程度予測できる (Fig. 15, Fig. 20, Fig. 21)。また $\mathrm{MMD}_{1}$ は $\mathrm{MMD}_{0}$ のべき関数として決ま り，ある粒径以上になると室内にほとんど流入しない

(Fig. 16, Fig. 17, Fig. 22)。

2）開口条件で空開放時と閉鎖時を比較すると，I/O 比は常に空開放時の方が大であり，1に近い。このこと は，一般に換気量が大になると，I/O 比が大になる傾向 を示している。しかし，現実には外気粉䴤濃度と粒径分 布は発生源，外部風などにより変化するし，またその室 内への影響は，開口条件，換気量などにより変わる。こ れらの要囚が互いに複雑に関係しあっている。 
3）今回の測定では，風速大になると，外気濃度は小 となり (Fig. 10)， $\mathrm{MMD}_{0}$ は大となる (Fig. 9)。その 結果, I/O 比は小なる傾向を示すはずであるが結果は逆 であった。(Fig.11, Fig.12, Fig.19)。一方, 風速大 になると, 開口条件一定ならば，換気量は大となり

(Fig. 6)，I/O 比は大になる傾向を示すはずである。

したがって, 風速変化による換気量と $\mathrm{MMD}_{0}$ の変化 がI/O比に対して相反する作用をしており，外気濃度 と粒径分布だけから $\mathrm{I} / \mathrm{O}$ 比を決めることができないこ とがわかった。すなわち, 空閉鎖時, 外気濃度が大にな るとき， $\mathrm{MMD}_{0}$ が小さくなり，I/O 比は大になると考 えられるが逆の結果を得た。これは, 濃度が大のとき, 風速小で換気量も小さく, この換気効果が強く影響し, I/O 比は小さくなったと解釈できる。

以上, 室内外の粉塵, 金属, イオンの濃度とその粒径 分布の関連を調べてきたが, 外気濃度と I/O 比の関連 は一義的には決まらず，その粒径分布，開口条件，換気 量などを明確にして論じなければならない。また，この 意味から室内外の金属, イオンの分析は価值あるものと 考えられる。

なお，今後は一層多くの I/O 比とその諸要因との関 連を決める資料を積み重的る必要があろう。

また, 外気粉塵濃度とその発生源や気象条件との関連 や喫煙なよ゙室内発生のある場合のその室内での寄与なよ゙ について調査する必要があろう。

\section{参考文献}

1）長良健次：室内浮遊塺の粒径分布と元素組成について, 空気清浄，第 22 巻，第 6 号, pp. $28 \sim 31,1985$

2）竹内貢三ほか 2 名：室内浮遊粉塵中の金属成分について, 空気清浄，第 12 巻，第 2 号, pp. 33 42, 1974

3) D. J. Moschandreas et al. : Fine Particle Residential Indoor Air Pollution, Atmospheric Environment, Vol. 13, pp. 1413 1418, 1979

4）石堂正三郎ほか 2 名：住居内の空気条件について，特に
塺あい数及び細菌数についての考察, 大阪市立大学家政 学部紀要, 第 3 巻, 第 4 号, pp. 127 135, 1955

5) J.E. Yocom et al. : Indoor/Outdoor Air Quality Relationships, A.P.C.A., Vol.21, No.5, pp. 251 259, 1971

6) F.B. Benson et al. : Indoor-Outdoor Air Pollution Relationșhips: A Literature Review, E. P. A. 1972

7) C.R. Thompson et al. : Outdoor-Indoor Levels of Six Air Pollutants, A.P.C.A., Vol.23, No.10, pp.881 886, 1973

8) A.F. Cohen et al. : Protection from being Indoors against Inhalation of Suspended Particulate Matter of Outdoor Origin, Atmospheric Environment, Vol.14, pp. 183 184, 1980

9) K. Biersteker et al. : Indoor Air Pollution in Rotterdam Homes, Int. J. Air Wat. Poll. Vol.9, pp. 343 350, 1965

10) Ib Andersen : Relationships between Outdoor and Indoor Air Pollution, Atmospheric Environment, Vol.6, pp. 275 278, 1972

11) J. Alzona et al. : Indoor-Outdoor Relationships for Airborne Particulate Matter of Outdoor Origin, Atmospheric Environment, Vol.13, pp. 55 60, 1979

12）宮崎竹二ほか 2 名：大阪市立環境科学研究所調查研究年 報，44，pp.19２3，1981

13）宮崎竹二，梄崎正也：室内環境における粉塵および金属 濃度 その1, 外気由来の粉塵および金属濃度とそれら の粒径分布, 日本建築学会大会学術講演梗概集, pp. 1201 1202, 昭和 62 年 10 月

14）宮崎竹二，梄崎正也：室内環境における粉塺および金属 濃度その2, 換気之粉塵および金属濃度, 日本建築学 会大会学術講演梗概集, pp. 797 798, 昭和 63 年 10 月

15）宮崎竹二，粞崎正也：室内環境における粉塵および金属 濃度 その3, 事務室および住宅における実測例, 日本 建築学会大会学術講演梗概集, pp. 647 648, 1989

16）角脇 怜：大気浮遊粉じん中のケイ素およびアルミニウ 么の粒度分布と濃度比, 日本化学会誌, pp. 1911 1916, 1977

(1991 年 3 月 30 日原稿受理，1991 年 12 月 9 日採用決定)

\section{英文要約 (Summary)}

Concentrations and size distributions of the particulate dusts and metals in indoor and outdoor air were measured in the expepimental room with Andersen air sampler and low volume air sampler.

It was shown that Indoor/Outdoor concentration ratios and logarithm of MMD for the particulate dusts and metals were correlated closely. I/O concentration ratios and MMD of the indoor particulate dusts and metals when the window was opened, much increased than them when the window was closed. Similar measurement was carried out in a private house to confirm the results above.

From the results of investigation, we can introduce that $I / O$ concentration ratios are estimated approximately under the conditions of the given ventilation rates and the windows when the concentration and the size distribu- 
tion of outdoor particulate dusts and metals are obtained.

But the changes of wind velocity and direction bring the changes of outdoor concentration and size distribution, and at the same time the ventilation rates make change also. Therefore it is found to be hard to estimate I/O ratios. 